\title{
KEMAMPUAN EKSTRAK DAUN PEPAYA (Carica papaya L.) UNTUK MEMATIKAN LARVA NYAMUK Aedes aegypti dan Culex sp La Taha ${ }^{1}$ dan Nur Inang ${ }^{2}$ \\ 1.2 Poltekkes Kemenkes Makassar \\ nurinang1996@gmail.com
}

\begin{abstract}
Vector is an insect or other animals that usually carrying agents one of the Aedes aegypti mosquitoes is mosquito cause dengue hemorrhagic disease (DBD) and mosquito Culex can cause disease of Japanese Encephalitis (brain inflammation) and filariasis. In 2015 Bone Regency has included in the highest category of dengue fever in South Sulawesi as many as 777 cases. And for the case of filariasis of the highest category in Pangkep district were 116 cases. The purpose of this study was to determine the ability of papaya leaf extract (Carica papaya L.) to kill larvae Aedes aegypti and Culex sp. The type of research used is experimental, namely to determine the ability of papaya leaf extract (Carica papaya $L$ ) to kill the larvae of Aedes aegypti and Culex sp mosquitoes with a total of 480 samples. The results of this study indicate that larvae Aedes aegypti and Culex Sp papaya leaf extract to kill larvae Aedes aegypti with concentration of $10 \%$ as much as $43.3 \%, 15 \%$ as much as $73 \%$ and concentration of $20 \%$ as much as $98.1 \%$ and Culex Sp with concentration of $10 \%$ as much as $28.3 \%$, the concentration of $15 \%$ was $44.9 \%$ and the concentration of $20 \%$ was $69.8 \%$ The conclusion of this study showed that Papaya Leaf Extract (Carica papaya L.) able to kill instar larvae III Aedes aegypti and Culex Sp mosquitoes with concentration 15\% and 20\% with time 12 hours.

Keywords: Papaya Leaf Extract, Culex, Aedes Aegypti.
\end{abstract}

\section{ABSTRAK}

Vektor merupakan serangga atau hewan lain yang biasanya membawa agent salah satunya nyamuk Aedes aegypti merupakan nyamuk penyebab penyakit demam berdarah dengue (DBD) serta nyamuk Culex sp dapat menyebabkan penyakit Japanese Entephalitis (radang otak) dan Filiriasis. Tahun 2015 Kabupaten Bone termasuk dalam kategori tertinggi penyakit DBD di Sulawesi Selatan sebanyak 777 kasus. Dan untuk kasus filariasis kategori tertnggi pada kabupaten Pangkep sebanyak 116 kasus. Tujuan penelitian ini adalah untuk mengetahui kemampuan ekstrak daun papaya (Carica papaya L.) untuk mematikan larva Aedes aegypti dan Culex sp. Jenis penelitian yang digunakan adalah bersifat eksperimen, yaitu untuk mengetahui kemampuan ekstrak daun papaya (Carica papaya $L$ ) untuk mematikan larva nyamuk Aedes aegypti dan Culex sp dengan jumlah sampel sebanyak 480 ekor. Hasil penelitian ini menunjukkan bahwa larva Aedes aegypti dan Culex sp ekstrak daun papaya untuk mematikan larva Aedes aegypti dengan konsentrasi 10\% sebanyak 43,3\%, 15\% sebanyak $73 \%$ dan konsentrasi $20 \%$ sebanyak $98,1 \%$ dan Culex Sp dengan konsentrasi $10 \%$ sebanyak 28,3\%, konsentrasi $15 \%$ sebanyak $44,9 \%$ dan konsentrasi $20 \%$ sebanyak $69,8 \%$. Kesimpulan dari penelitian ini menunjukkan bahwa Ekstrak Daun Pepaya (Carica papaya L.) mampu mematikan larva instar III nyamuk Aedes aegypti dan Culex sp dengan konsentrasi 15\% dan 20\% dengan waktu 12 jam

Kata Kunci : Ekstrak Daun Pepaya, Culex, Aedes Aegypti.

\section{PENDAHULUAN}

Nyamuk Aedes aegypti merupakan nyamuk penyebab penyakit demam berdarah dengue (DBD) yang masih menjadi masalah kesehatan masyarakat dan Nyamuk Culex sp merupakan golongan serangga penular (vektor) nyamuk dari genus Culex sp dapat menyebabkan penyakit Japanese Entephalitis (radang otak) dan Filiriasis.sehingga perlu dilakukan pengendalian untuk mencegah penyebaran nyamuk Aedes aegypti dan Culex sp. seperti penggunaan larvasida nabati untuk membunuh larva nyamuk Aedes aegypti dan Culex sp.

Salah satu alternative yang perlu untuk pemberantasan larva Aedes aegypti dan Culex $s p$ yaitu dengan menggunakan Insektisida nabati Oleh karena terbuat dari bahan alami maka jenis insektisida ini mudah terurai (biodegradable) di alam sehingga tidak mencemari lingkungan dan relatif aman bagi manusia dan ternak peliharaan karena residunya mudah hilang.
Tanaman pepaya merupakan tanaman yang banyak diteliti saat ini karena hampir seluruh bagian tanamannya dapat dimanfaatkan baik daun, getah, biji, akar, batang, dan buahnya. Tanaman pepaya merupakan tanaman suku Caricaceae marga Carica yang merupakan herbal berasal dari Amerika tropis dan cocok juga untuk ditanam di Indonesia. Senyawa aktif yang terdapat pada tanaman papaya yaitu enzim papain, karotenoid, alkaloid, monoterpenoid, flavonoid, mineral, vitamin, glukosinolat, karposida.Tanaman pepaya telah banyak digunakan oleh masyarakat sejak dulu. Secara empiris pepaya banyak digunakan sebagai diuretik (akar \& daun), anthelmintic (biji \& daun), dan untuk menyembuhkan penyakit akibat empedu (buah), serta dyspepsia dan kelainan pencernaan lainnya (Septiani R, 2016).

Berdasarkan uji pendahuluan yang telah dilakukan pada tanggal 19 januari 2018 oleh peneliti didapatkan hasil bahwa kemampuan ekstrak daun pepaya (Carica papaya L.) dengan 
konsentrasi $15 \%$ membutuhkan waktu selama 8 jam untuk mampu mematikan larva Aedes aegypti sebanyak 10 larva dari 10 sampel larva sedangkan larva culex $s p$ membutuhkan waktu selama 11 jam untuk mematikan larva sebanyak 10 larva dari 10 sampel larva dengan waktu pengamatan selama 12 jam. Hal ini disebabkan karena komponen utama dalam daun papaya (Carica papaya L.) yaitu zat papain, alkaloid, dan flavonoid yang mampu mematikan larva Aedes aegypti dan Culex sp.

\section{Bahan dan Metode}

\section{Lokasi Penelitian}

Penelitian ini dilakukan di laboratorium Jurusan Kesehatan Lingkungan Politeknik Kesehatan Makassar.

\section{Desain dan Variabel Penelitian}

a. Desain Penelitian

Nyamuk Aedes aegypti merupakan nyamuk penyebab penyakit demam berdarah dengue (DBD) yang masih menjadi masalah kesehatan masyarakat dan Nyamuk Culex sp merupakan golongan serangga penular (vektor) nyamuk dari genus Culex $s p$ dapat menyebabkan penyakit Japanese Entephalitis (radang otak) dan Filiriasis pecegahan dapat dilakukan dengan pengendalian terhadap vektor melalui pemberantasan larva nyamuk Aedes dan Culex. Penggunaan abate dalam mengendalikan jentik nyamuk Aedes aegypti dan Culex $s p$ dapat menyebabkan resistensi sehingga salah satu alternative yang dapat digunakan untuk memberantas larva nyamuk.Adalah dengan menggunakan larvasida nabati seperti daun pepaya. Kandungan yang ada pada daun pepaya tersebut yang diduga memiliki potensi sebagai larvasida adalah enzim papain, saponin, flavonoid, dan tanin.

b. Variabel Penelitian

Variabel bebas dalam penelitian ini adalah ekstrak daun pepaya dengan konsentrasi $10 \%, 15 \%$, dan $20 \%$. Variabel terikat dalam penelitian ini adalah jumlah kematian larva nyamuk Aedes aegypti dan Culex sp.

\section{Populasi}

Populasi yang dalam penelitian ini adalah larva nyamuk Aedes aegypti sebanyak 240 dan larva Culex sp sebanyak 240 larva.

\section{Sampel}

Sampel dalam penelitian ini adalah larva nyamuk Aedes aegypti dan Culex sp yang diambil langsung dari Entomologi Fakultas Kesehatan Masyarakat Universitas Hasanuddin Makassar. Pengambilan sampel dilakukan secara total sampling. sampel dalam penelitian ini dilakukan sebanyak 3 kali perlakuan sehingga Jumlah keseluruhan sampel dalam penelitian ini sebanyak 480 larva, dimana larva nyamuk Aedes aegypti sebanyak 240 larva dan larva nyamuk Culex sp sebanyak 240 larva untuk setiap konsentrasi $10 \%, 15 \%$, dan $20 \%$ dan kontrol. Setiap konsentrasi sampel yang digunakan sebanyak 20 larva Aedes aegypti dan Culex sp.

\section{Metode Pengumpulan Data}

a. Data Primer

Data primer adalah data yang diperoleh melalui hasil pengamatan langsung selama melakukan penelitian di lapangan.

b. Data Sekunder diperoleh melalui penelusuran kepustakaan berupa referensi dari $\mathrm{KTI}$, jurnal, artikel-artikel, buku maupun literatur dan hasil internet yang dianggap memiliki keterkaitan dengan penelitian ini.

\section{Teknik Analisa Data}

Setiap hasil uji pengamatan akan disajikan dalam bentuk tabel, kemudian dianalisa dan diuraikan secara deskriptif sehingga dapat diperoleh suatu kesimpulan yang layak.

\section{Hasil}

Berdasarkan penelitian yang telah dilakukan di laboratorium jurusan Kesehatan Lingkungan Politeknik Kesehatan Makassar pada tanggal 25 Mei 2018. Kemampuan Ekstrak daun papaya (carica papaya L.) sebagai larvasida untuk mematikan larva Aedes aegypti dan larva Culex sp dengan jumlah sampel 20 ekor dan konsentrasi $10 \%, 15 \%$ dan $20 \%$. waktu pengamatan selama 12 jam dan dalam penelitian ini dilakukan sebanyak 3 kali perlakuan diproleh hasil sebagai berikut :

\section{Populasi dan Sampel}


1. Kemampuan Ekstrak Daun Pepaya dengan Konsentrasi $10 \%$ Untuk Mematikan larva Aedes aegypti

Tabel 1

Kemampuan Ekstrak Daun Pepaya (Carica Papaya L.)Untuk Mematikan Larva Aedes aegypti Dengan Konsentrasi 10\%

\begin{tabular}{|c|c|c|c|c|c|c|c|c|c|}
\hline \multirow[b]{2}{*}{$\begin{array}{l}\mathbf{N} \\
\mathbf{0}\end{array}$} & \multirow{2}{*}{$\begin{array}{l}\text { Waktu } \\
\text { Penga } \\
\text { matan }\end{array}$} & \multicolumn{6}{|c|}{$\begin{array}{l}\text { Jumlah Kematian Larva } \\
\text { Dalam Tiga Perlakauan }\end{array}$} & \multirow{2}{*}{$\begin{array}{l}\text { Rata - } \\
\text { Rata } \\
\text { Kemati } \\
\text { an (\%) }\end{array}$} & \multirow[b]{2}{*}{$\begin{array}{l}\text { Kont } \\
\text { rol }\end{array}$} \\
\hline & & I & $\%$ & I & $\%$ & II & $\%$ & & \\
\hline 1 & 2 Jam & 2 & 10 & 1 & 5 & 2 & $\begin{array}{l}1 \\
0\end{array}$ & 8,3 & 0 \\
\hline 2 & 4 Jam & 1 & 5 & 3 & 15 & 3 & $\begin{array}{l}1 \\
5\end{array}$ & 11,6 & 0 \\
\hline 3 & $6 \mathrm{Jam}$ & 2 & 10 & 2 & 10 & 1 & 5 & 8,3 & 0 \\
\hline 4 & 8 Jam & 4 & 20 & 3 & 15 & 3 & $\begin{array}{l}1 \\
5\end{array}$ & 16,6 & 0 \\
\hline 5 & Jam $^{10}$ & 2 & 10 & 1 & 5 & 1 & 5 & 6,6 & 0 \\
\hline 6 & Jam $^{12}$ & 4 & 20 & 5 & 25 & 4 & $\begin{array}{l}2 \\
0 \\
\end{array}$ & 21,6 & 0 \\
\hline & Total & 15 & 75 & $\begin{array}{l}1 \\
5\end{array}$ & 75 & $\begin{array}{l}1 \\
4 \\
\end{array}$ & $\begin{array}{l}7 \\
0 \\
\end{array}$ & 73 & 0 \\
\hline
\end{tabular}

2. Kemampuan Ekstrak Daun Pepaya dengan Konsentrasi $15 \%$ Untuk Mematikan larva Aedes aegypti

Tabel 2

Kemampuan Ekstrak Daun Pepaya (Carica Papaya L.)Untuk Mematikan

Larva Aedes aegypti Dengan Konsentrasi 15\%

\begin{tabular}{|c|c|c|c|c|c|c|c|c|c|}
\hline \multirow[b]{2}{*}{ No } & \multirow{2}{*}{$\begin{array}{l}\text { Waktu } \\
\text { Penga } \\
\text { matan }\end{array}$} & \multicolumn{6}{|c|}{$\begin{array}{l}\text { Jumlah Kematian Larva Dalam } \\
\text { Tiga Perlakuan }\end{array}$} & \multirow{2}{*}{$\begin{array}{l}\text { Rata } \\
- \\
\text { Rata } \\
\text { Kem } \\
\text { atian } \\
(\%)\end{array}$} & \multirow{2}{*}{$\begin{array}{l}\text { Kont } \\
\text { rol }\end{array}$} \\
\hline & & I & $\%$ & II & $\%$ & III & $\%$ & & \\
\hline 1 & 2 Jam & 3 & 15 & 2 & 10 & 3 & 15 & 13,3 & 0 \\
\hline 2 & 4 Jam & 3 & 15 & 4 & 20 & 3 & 15 & 16,6 & 0 \\
\hline 3 & 6 Jam & 3 & 15 & 4 & 20 & 2 & 10 & 15 & 0 \\
\hline 4 & 8 Jam & 4 & 20 & 3 & 15 & 4 & 20 & 18,3 & 0 \\
\hline 5 & $10 \mathrm{Jam}$ & 2 & 10 & 4 & 20 & 5 & 25 & 18,3 & 0 \\
\hline 6 & 12 Jam & 5 & 25 & 2 & 10 & 3 & 15 & 16,6 & 0 \\
\hline & Total & $\begin{array}{l}2 \\
0\end{array}$ & $\begin{array}{l}10 \\
0\end{array}$ & $\begin{array}{l}1 \\
9\end{array}$ & 95 & 20 & $\begin{array}{l}10 \\
0\end{array}$ & 98,1 & 0 \\
\hline
\end{tabular}

3. Kemampuan Ekstrak Daun Pepaya dengan Konsentrasi $15 \%$ Untuk Mematikan larva Aedes aegypti
Tabel 3

Kemampuan Ekstrak Daun Pepaya (Carica Papaya L.) Untuk Mematikan Larva Aedes Aegypti Dengan Konsentrasi 20\%

\begin{tabular}{|c|c|c|c|c|c|c|c|c|c|}
\hline \multirow[b]{2}{*}{ No } & \multirow{2}{*}{$\begin{array}{l}\text { Wakt } \\
\text { u } \\
\text { Peng } \\
\text { amat } \\
\text { an }\end{array}$} & \multicolumn{6}{|c|}{$\begin{array}{l}\text { Jumlah Kematian Larva Dalam Tiga } \\
\text { Perlakuan }\end{array}$} & \multirow{2}{*}{$\begin{array}{l}\text { Rat } \\
\text { a - } \\
\text { Rat } \\
\text { a } \\
\text { Ke } \\
\text { mat } \\
\text { ian } \\
(\%)\end{array}$} & \multirow[b]{2}{*}{$\begin{array}{l}\text { Ko } \\
\text { ntr } \\
\text { ol }\end{array}$} \\
\hline & & I & $\%$ & II & $\%$ & III & $\%$ & & \\
\hline 1 & $\begin{array}{l}2 \\
\text { Jam }\end{array}$ & 2 & 10 & - & 0 & 1 & 5 & 5 & 0 \\
\hline 2 & $\begin{array}{l}4 \\
\text { Jam }\end{array}$ & - & 0 & 3 & 15 & 1 & 5 & 6,6 & 0 \\
\hline 3 & $\begin{array}{l}6 \\
\text { Jam }\end{array}$ & 2 & 10 & 2 & 10 & 2 & 10 & 10 & 0 \\
\hline 4 & $\begin{array}{l}8 \\
\text { Jam }\end{array}$ & 2 & 10 & 1 & 5 & 2 & 10 & 8,3 & 0 \\
\hline 5 & $\begin{array}{l}10 \\
\text { Jam }\end{array}$ & 1 & 5 & 1 & 5 & 2 & 10 & 5 & 0 \\
\hline \multirow[t]{2}{*}{6} & $\begin{array}{l}12 \\
\text { Jam }\end{array}$ & 1 & 5 & 2 & 10 & 1 & 5 & 6,6 & 0 \\
\hline & Total & 8 & 40 & 9 & 45 & 9 & 45 & $\begin{array}{l}41, \\
6\end{array}$ & 0 \\
\hline
\end{tabular}

4. Kemampuan Ekstrak Daun Pepaya dengan Konsentrasi $10 \%$ Untuk Mematikan larva Culex sp

Tabel 4

Kemampuan Ekstrak Daun Pepaya (Carica Papaya L.)Untuk Mematikan Larva Culex Sp Dengan Konsentrasi 10\%

\begin{tabular}{|c|c|c|c|c|c|c|c|c|c|}
\hline \multirow[b]{2}{*}{$\begin{array}{l}\mathbf{N} \\
\mathbf{O}\end{array}$} & \multirow{2}{*}{$\begin{array}{l}\text { Waktu } \\
\text { Penga } \\
\text { matan }\end{array}$} & \multicolumn{6}{|c|}{$\begin{array}{l}\text { Jumlah Kematian Larva Dalam } \\
\text { Tiga Perlakuan }\end{array}$} & \multirow{2}{*}{$\begin{array}{l}\text { Rata } \\
\text { Rata } \\
\text { Kem } \\
\text { atian } \\
(\%)\end{array}$} & \multirow[b]{2}{*}{$\begin{array}{l}\text { Kont } \\
\text { rol }\end{array}$} \\
\hline & & I & $\%$ & $\begin{array}{l}\text { I } \\
\text { I }\end{array}$ & $\%$ & III & $\%$ & & \\
\hline 1 & 2 Jam & - & 0 & 1 & 5 & 1 & 5 & 3,3 & 0 \\
\hline 2 & 4 Jam & 2 & 10 & - & 0 & 1 & 5 & 5 & 0 \\
\hline 3 & 6 Jam & 2 & 10 & 2 & 10 & - & 0 & 6,7 & 0 \\
\hline 4 & 8 Jam & - & 0 & 1 & 5 & 2 & 10 & 5 & 0 \\
\hline 5 & $10 \mathrm{Jam}$ & 1 & 5 & - & 0 & 2 & 10 & 5 & 0 \\
\hline 6 & 12 Jam & 1 & 5 & 1 & 5 & - & 0 & 3,3 & 0 \\
\hline & Total & 6 & 30 & 5 & 25 & 6 & 30 & 28,3 & 0 \\
\hline
\end{tabular}

5. Kemampuan Ekstrak Daun Pepaya dengan Konsentrasi $15 \%$ Untuk Mematikan larva Culex sp 
Tabel 5

Kemampuan Ekstrak Daun Pepaya (Carica Papaya L.)Untuk Mematikan Larva Culex Sp Dengan Konsentrasi $15 \%$

\begin{tabular}{lllllllllll}
\hline & $\begin{array}{l}\text { Waktu } \\
\text { Pengam } \\
\text { atan }\end{array}$ & \multicolumn{1}{c}{$\begin{array}{l}\text { Jumlah Kematian Larva Dalam } \\
\text { No }\end{array}$} & I & $\%$ & I & $\%$ & III & $\begin{array}{l}\text { Rata } \\
- \\
\text { Rata } \\
\text { Kem } \\
\text { atian } \\
(\%)\end{array}$ & $\begin{array}{l}\text { Ko } \\
\text { ntr } \\
\text { ol }\end{array}$ \\
1 & 2 Jam & 1 & 5 & 2 & 10 & 2 & 10 & 8,3 & 0 \\
2 & 4 Jam & 2 & 10 & 2 & 10 & 3 & 15 & 11,7 & 0 \\
3 & 6 Jam & - & 0 & 1 & 5 & - & 0 & 1,6 & 0 \\
4 & 8 Jam & 2 & 10 & - & 0 & 2 & 10 & 6,6 & 0 \\
5 & $10 \mathrm{Jam}$ & 1 & 5 & 2 & 10 & - & 0 & 5 & 0 \\
6 & $12 \mathrm{Jam}$ & 3 & 15 & 1 & 5 & 3 & 15 & 11,6 & 0 \\
\hline & Total & $\mathbf{9}$ & $\mathbf{4 5}$ & $\mathbf{8}$ & $\mathbf{4 0}$ & $\mathbf{1 0}$ & $\mathbf{5 0}$ & $\mathbf{4 4 , 9}$ & $\mathbf{0}$ \\
\hline
\end{tabular}

6. Kemampuan Ekstrak Daun Pepaya dengan Konsentrasi 20\% Untuk Mematikan larva Culex sp

Tabel 6

Kemampuan Ekstrak Daun Pepaya (Carica Papaya L.) Untuk Mematikan Larva Culex Sp Dengan Konsentrasi $20 \%$

\begin{tabular}{|c|c|c|c|c|c|c|c|c|c|}
\hline \multirow[b]{2}{*}{$\begin{array}{l}\mathbf{N} \\
\mathbf{O}\end{array}$} & \multirow{2}{*}{$\begin{array}{l}\text { Waktu } \\
\text { Pengamat } \\
\text { an }\end{array}$} & \multicolumn{6}{|c|}{$\begin{array}{l}\text { Jumlah Kematian Larva } \\
\text { Dalam Tiga Perlakuan }\end{array}$} & \multirow{2}{*}{$\begin{array}{l}\text { Rata - } \\
\text { Rata } \\
\text { Kemati } \\
\text { an (\%) }\end{array}$} & \multirow[b]{2}{*}{$\begin{array}{l}\text { Kont } \\
\text { rol }\end{array}$} \\
\hline & & I & $\%$ & II & $\%$ & III & $\%$ & & \\
\hline 1 & 2 Jam & 4 & $\begin{array}{l}2 \\
0\end{array}$ & 3 & $\begin{array}{l}1 \\
5\end{array}$ & 3 & 15 & 16,6 & 0 \\
\hline 2 & 4 Jam & 3 & $\begin{array}{l}1 \\
5\end{array}$ & 3 & $\begin{array}{l}1 \\
5\end{array}$ & 2 & 10 & 13,3 & 0 \\
\hline 3 & $6 \mathrm{Jam}$ & - & 0 & 4 & $\begin{array}{l}2 \\
0\end{array}$ & 4 & 20 & 13,3 & 0 \\
\hline 4 & 8 Jam & 3 & $\begin{array}{l}1 \\
5\end{array}$ & - & 0 & 2 & 10 & 8,3 & 0 \\
\hline 5 & $10 \mathrm{Jam}$ & - & 0 & 2 & $\begin{array}{l}1 \\
0\end{array}$ & - & 0 & 3,3 & 0 \\
\hline 6 & 12 Jam & 4 & $\begin{array}{l}2 \\
0\end{array}$ & 3 & $\begin{array}{l}1 \\
5\end{array}$ & 2 & 10 & 15 & 0 \\
\hline & Total & $\begin{array}{l}1 \\
4\end{array}$ & $\begin{array}{l}7 \\
0\end{array}$ & $\begin{array}{l}1 \\
5\end{array}$ & $\begin{array}{l}7 \\
5\end{array}$ & $\begin{array}{l}1 \\
3\end{array}$ & 65 & 69,8 & 0 \\
\hline
\end{tabular}

Pembahasan

1. Kemampuan Ekstrak Daun Pepaya (Carica papaya $L$.) Dengan Konsentrasi $10 \%$ Dalam Mematikan Larva Nyamuk Aedes aegypt

Ekstrak daun pepaya dengan konsentrasi $10 \%$ belum mampu dalam mematikan larva nyamuk Aedes aegypti karena $\leq 50 \%$ sesuai dengan LC50 setelah pengamatan selama 12 jam rata - rata kematian larva nyamuk Aedes aegypti sebanyak $43,2 \%$ dan untuk kontrol tidak ada larva nyamuk Aedes aegypti yang mati. Efek larvasida ekstrak daun pepaya ini disebabkan oleh komponen senyawa aktif yang terkandung di dalam daun pepaya yaitu alkaloid, saponin, flavonoid, dan enzim papain. Senyawa alkaloid yang terdapat pada daun pepaya adalah alkaloid karpain. Senyawa alkaloid bekerja dengan cara menghambat aktifitas enzim asetylcholinesterase yang mempengaruhi transmisi impuls saraf sehingga menyebabkan enzim tersebut mengalami fosforilasi dan menjadi tidak aktif. Hal ini akan mengakibatkan terhambatnya proses degradasi acetylcholine sehingga terjadi akumulasi acetylcholine di celah sinap. Kondisi ini menyebabkan terjadinya gangguan transmisi yang dapat menyebabkan menurunnya koordinasi otot, konvulsi, gagal nafas dan kematian.

2. Kemampuan Ekstrak Daun Pepaya (Carica papaya $L$.) Dengan Konsentrasi $15 \%$ Dalam Mematikan Larva Nyamuk Aedes aegypti

Ekstrak daun pepaya dengan konsentrasi $15 \%$ mampu mematikan larva nyamuk Aedes aegypti sebanyak $73 \%$ karena $\geq 50 \%$ sesuai dengan LC50 selama 12 jam pengamatan. Persentase kematian larva nyamuk Aedes aegypti dengan konsentrasi $15 \%$ mengalami peningkatan jika dibandingkan dengan konsentrasi $10 \%$, hal ini disebabkan karena semakin tinggi konsentrasi ekstrak daun pepaya maka semakin tinggi persentase kematian larva nyamuk Aedes aegypti.Kandungan papain merupakan enzim proteolitik yang berproses dalam pemecahan jaringan ikat, Apabila enzim papain ini masuk kedalam tubuh Aedes aegypti akan mempengaruhi proses metabolism tubuh dimana terjadi suatu reaksi kimia yang dapat menyebabkan terhambatnya hormone pertumbuhan sehingga larva tidak dapat berkembang dengan baik dan lama kelamaan dapat menyebabkan kematian larva.

3. Kemampuan Ekstrak Daun Pepaya (Carica papaya L.) Dengan Konsentrasi $20 \%$ Dalam Mematikan Larva Nyamuk Aedes aegypti

Ekstrak daun pepaya dengan konsentrasi $20 \%$ lebih mampu dalam mematikan nyamuk Aedes aegypti karena dengan rata-rata kematian sebanyak $98,1 \%$ $\geq 50 \%$ sesuai LC50 dalam waktu pengamatan selama 12 jam. Persentase kematian larva nyamuk Aedes aegypti dengan konsentrasi $20 \%$ mengalami penigkatan jika dibandingkan dengan konsentrasi $10 \%$ dan 15\%. karena semakin tinggi konsentrasi ekstrak daun pepaya maka semakin tinggi presentasi kematian larva nyamuk dan semakin pekat ekstrak daun papaya pada konsentrasi $20 \%$ 
sesuai kriteria objektif menyatakan bahwa ekstrak dapat dikatakan mampu apabila dapat mencapai angka mortalitas $50 \%$ sampel pengujian yaitu larva.Krishna (2008). mengemukakan bahwa bagian tanaman buah papaya seperti akar, daun, buah, dan biji mengandung bahan aktif yang dapat dijadikan sebagai obat. metode yang paling efektif untuk mengendalikan nyamuk Aedes aegypti adalah dengan cara membunuh larvanya, sehingga dapat memutus siklus hidup nyamuk tersebut.

4. Kemampuan Ekstrak Daun Pepaya (Carica papaya $L$.) Dengan Konsentrasi $10 \%$ Dalam Mematikan Larva Nyamuk Culex sp

Ekstrak daun pepaya dengan konsentrasi $10 \%$ belum mampu mematikan larva nyamuk Culex sp karena $\leq 50 \%$ sesuai dengan LC50 setelah pengamatan selama 12 jam diperoleh persentase kematian larva nyamuk Culex sp rata-rata sebanyak $28,3 \%$, dan untuk kontrol tidak ada larva nyamuk Culex sp yang mati.Kematian larva nyamuk Culex $s p$ hal ini disebabkan adanya kandungan papain yang ada pada daun papaya yang merupakan enzim proteolitik yang berproses dalam pemecahan jaringan ikat. Apabila enzim papain ini masuk ke dalam tubuh larva akan mempengaruhi proses metabolisme tubuh dimana terjadi suatu reaksi kimia yang dapat menyebabkan terhambatnya hormon pertumbuhan sehingga larva tidak dapat berkembang dengan baik dan lama kelamaan dapat menyebabkan kematian pada larva.

5. Kemampuan Ekstrak Daun Pepaya (Carica papaya $L$.) Dengan Konsentrasi $15 \%$ Dalam Mematikan Larva Nyamuk Culex sp

Ekstrak daun pepaya dengan konsentrasi $10 \%$ belum mampu dalam mematikan larva nyamuk Culex $s p$ karena $\leq$ $50 \%$ sesuai dengan LC50 setelah pengamatan selama 12 jam rata - rata kematian larva nyamuk Culex sp sebanyak $44,9 \%$ dan untuk kontrol tidak ada larva nyamuk Culex $s p$ yang mati.Persentase kematian larva nyamuk Culex $s p$ dengan konsentrasi $15 \%$ mengalami penigkatan dibandingkan dengan konsentrasi $10 \%$, hal ini disebabkan karena semakin tinggi konsentrasi ekstrak daun pepaya maka semakin tinggi presentasi kematian larva nyamuk Culex sp. Meski mengalami peningkatan kematian tapi masih belum efektif dalam mematikan nyamuk Culex sp kematian larva nyamuk $\leq 50 \%$ sesuai LC50.Kematian larva nyamuk Culex $s p$ hal ini disebabkan kandungan saponin yang ada pada daun papaya bersifat racun bagi hewan berdarah dingin yaitu dengan menghancurkan butir darah merah lewat reaksi hemolisis.

6. Kemampuan Ekstrak Daun Pepaya (Carica papaya $L$.) Dengan Konsentrasi $20 \%$ Dalam Mematikan Larva Nyamuk Culex sp

Ekstrak daun pepaya dengan konsentrasi $20 \%$ mampu mematikan larva nyamuk Culex sp karena $\geq 50 \%$ sesuai dengan LC50 setelah pengamatan selama 12 jam rata - rata kematian larva sebanyak $69,8 \%$. dan untuk kontrol tidak ada larva nyamuk Culex $s p$ yang mati.Dalam penelitian ini digunakan konsentrasi dari ekstrak daun papaya (Carica papaya L.) yang telah di uji pada masing masing kelompok larva. kematian larva uji seiring dengan bertambahnya konsentrasi dan waktu. Hal ini membuktikan bahwa semakin tinggi konsentrasi dan semakin lama pajamanan waktu maka semakin tinggi juga Kematian larva sesuai dengan teori menurut Hoedojo dan Zulhasril (2004), Khasiat insektisida untuk membunuh serangga bergantung pada bentuk, cara masuk kedalam tubuh serangga, macam bahan kimia, konsentrasi dan jumlah dosis insektisida.

Penelitian yang dilakukan Alboneh (2012) memberikan hasil bahwa ekstrak daun papaya memiliki potensi sebagai insektisida terhadap nyamuk Aedes aegypti dewasa,karena etanol daun papaya tersebut memiliki kandungan kimia Flavonoid yang akan mempengaruhi system pernapasan nyamuk. Penelitian lain yang dilakukan oleh Wicaksana tahun (2012), menyebut bahwa air perasan buah papaya (Carica papaya L.) dengan metode elektrik mempunyai efek sebagai insektisida nyamuk dengan Culex sp. dewasa konsentrasi $70 \%$ dapat mengakibatkan kematian nyamuk Culex sp. dewasa hingga $97 \%$. diketahui juga jika semakin tinggi konsentrasi yang digunakan maka makin tinggi pula tingkat kematian larva nyamuk.

Berdasarkan penelitian ini dan penelitian sebelumnya dapat diketahui bahwa daun papaya mampu sebagai insektisida nabati untuk mematikan larva nyamuk Aedes aegypti pada konsentrasi $15 \%$ sebanyak $73 \%$ sedangkan konsentrasi $20 \%$ mampu mematikan larva nyamuk Culex sp sebanyak $69,8 \%$ selama waktu pengamatan 12 jam. Oleh karena itu sebaiknya masayrakat memanfaatkan daun papaya sebagai insektisida nabati. banyak kekurangan, salah satunya yaitu larutan yang sudah dibuat berwarna hijau pekat dan menimbulkan bau yang tidak enak setelah 12 jam. Penelitian ini 
tidak meneliti bahan yang sangat efektif yang terkandung dalam daun papaya yang dapat membunuh larva. Adapun kelemahan dalam penelitian ini yaitu tidak akurat dalam membuat konsentrasi ekstrak daun papaya serta tidak melakukan pengukuran $\mathrm{pH}$ dan suhu pada saat penelitian berlangsung.

\section{Kesimpulan}

1. Kemampuan ekstrak daun papaya (Carica papaya L.) sebagai larvasida mampu mematikan larva nyamuk Aedes aegypti pada instar III dengan konsentrasi 15\% dan 20\% pada waktu pengamatan selama 12 jam.

2. Kemampuan ekstrak daun papaya (Carica papaya L.) sebagai larvasida mampu mematikan larva nyamuk Culex sp pada instar III dengan konsentrasi $20 \%$ pada waktu pengamatan selama 12 jam.

\section{Saran}

1. Bagi pemerintah diharapkan menerapkan penggunaan ekstrak daun papaya (Carica papaya L.) sebagai insektisida nabati untuk pengendalian vektor khususnya terhadap larva Aedes aegypti dan Culex Sp yang aman terhadap manusia dan lingkungan.

2. Bagi masayrakat yang akan menggunakan ekstrak daun papaya (Carica papaya L.) ini sangat mudah untuk mengaplikasikannya cukup menambah ekstrak daun papaya ini kedalam penampungan air.

\section{DAFTAR PUSTAKA}

Alboneh, F.H. 2012.Uji -Potensi Ekstrat Etanoldaun Papaya (Carica Papaya) Sebagai Insektisida Terhadap Nyamuk Aedes Sp Dengan Metode Listrik. (online/jurnal).http://ppjp.unlam.ac.id/journal/index.php./JPKMl/article/dwonload/2719/2368 Diakses pada tanggal 27 Desember 2017

Andriani, dkk. 2015. Uji Aktivitas Larvasida Terhadap Larva Culex Sp. Aedes Sp Dari Ekstrak Daun Alpukat. http://anzdoc.com/uji-larvasida-terhadap-larva-culex-sp-dan-aedes-sp.html.Diakses pada tanggal 18 Juli 2018.

Dinkes. 2016. Profil Kesehatan Provinsi Sulawesi Selatan. http://www. depkes.go.id/resources/download/pusdatin/profil-kesehatan-indonesia/profil.kesehatanindonesia 2016. pdf. (online/artikel). Diakses pada tanggal 28 Desember 2017

Hoedojo.R. Zulhasril. 2004 Insektisida dan Resistensi Parasitologi Kedokteran Edisi III. Fakultas Kedokteran Universitas Indonesia. Jakarta.

Indri Ramayanti, dkk.2016. Uji Efektivitas Larvasida Ekstrak Daun Pepaya (Carica Pepaya Lin) Terhadap Larva Aedes aegypti. (online/artikel). http: // journal. fkompalembang.ac.id/index-php/syifa medika/ article/ view/ 48/44.Diakses pada tanggal 28 Desember 2017.

Patrysia. Alvionita., dkk. 2013. Efek Ekstrak Daun Pepaya (carica papaya L.) Sebagai Larvasida Nyamuk Culex Sp. (online/artikel). http:// repository. maranatha. edu/12084/10/1010004_Journal.pdf. Diakses pada tanggal 26 Desember 2017.

Priyono. 2007. Manfaat dan Kandungan Dau Pepaya. Jakarta: Agromedia Pustaka.

Warisno. 2003. Budidaya Pepaya. Yogyakarta: Kanisius 